\title{
The Corporation: The Pathological PURSuIt of Profit and POWER, JOEl BaKaN (TORONTO: VIKING CaNada, 2004)
}

\section{INTRODUCTION}

If the corporation were a person, what would its personality be? In his provocative book The Corporation (and movie of the same title), Professor Joel Bakan argues that the corporation would be a psychopath. The corporation has become a vehicle by which good men and women cause harm to society because of the way the corporation is created and protected by the law. The author takes the reader through the origin of the corporation in form and legal status. He then parades a tale of terribles indicting the corporation for a variety of social ills afflicting the developing and developed worlds alike. They range from low wages in the third world, environmental damage, oppressing the masses, a slew of corporate crimes and many more. He then demonstrates how the corporation has been subverting the democratic process through donations and lobbying. Insidious marketing by corporations does not escape Bakan's wrath, and he ends by calling for corporate accountability. He proposes a variety of reforms that he believes will restore the balance of power from corporations back to the people.

Bakan's book takes issue with many aspects of the modern corporation. The book (and the movie) is worth reading (viewing) to get the full effect, and I shall confine my comments in this review to two points that Bakan addresses. ${ }^{1}$ The first is the claim that the modern corporation has caused its harm because this is the first time limited liability has effectively existed. The second point is his attack on the use of cost-benefit analysis by corporations when deciding on safety and health matters. I will highlight his main concerns in this essay, and offer some thoughts on them.

\section{The ORIGIN Of THE CORPORATION, StRUCTURALLy AND LEgally}

In the first chapter, Bakan outlines the origins of the corporation from the late seventeenth century to the early twentieth century. He starts with the South Sea Company, a tale of speculation in a company that ultimately collapsed, analogizing it to the modern sagas of Enron and other corporate meltdowns. The collapse of the South Sea Company led to heavy restrictions on the creation of joint stock companies, as they were known then, and Bakan alludes to these restrictions being desirable and needed today. In trying to explain the power of the modern corporation, he points out that the need for capital to finance the railways in the U.S. and the U.K. led to the creation of limited liability corporations all across the Atlantic. This was facilitated by the passage of various statutes on both sides of the Atlantic. In particular, Bakan points to the race between various states, such as New Jersey and Delaware, to attract corporations by passing permissive statutes that did not restrict their conduct. He also points to the United States Supreme Court's jurisprudence that recognized 
corporations as persons and gave them rights - rights that he claims protected corporations at the expense of the newly freed African-Americans. ${ }^{2}$ This, he claims, ended the grant theory of the corporation, a theory that corporations were granted their legitimacy by the state and hence only had a restricted mandate for what they could do and how long they could operate. By allowing corporations to exist as if they were live human beings, society has permitted corporations to dominate, rendering its shareholders and societics generally helpless against the power that typifies the modern corporation.

While Bakan does present both sides of the argument for why the limited liability corporation is an appropriate form of business association, he sways the reader to his view that the idea that liability is limited for the shareholder coupled with the separation of ownership and control has meant that the corporation can operate with impunity and no accountability. Implicit in Bakan's analysis are the ideas that limited liability corporations cannot exist absent a grant from the state and that modern limited liability somehow allowed the modern corporation to rise to prominence.

As to the claim that without the state, the corporation would not exist, the statement is true just as the statement that without the state, criminal law, or for that matter any statutory law, would not exist. Yet, no one would claim that absent the state, lawlessness would abound. In fact, there have been many episodes of history where peace and order prevailed despite the absence of any strong authority. Hence, the idea that the corporation could not exist absent a statutory grant is also suspect. A corporation in its modern form, perhaps, would not exist, but alternative forms would surely exist - in fact, they have over history.

There are two basic characteristics that a corporation has: limited liability and that the corporation is a separate entity that can operate separately from the sharcholders. First, while limited liability can be vicwed as a grant from the state, ${ }^{3}$ liability has always been practically limited by the wealth of the shareholder. Bankruptcy laws, however draconian, can never extract more than the existing assets out of a debtor - a no-water-from-stone rule. Second, the law of partnerships that has existed since ancient times, and the law of trusts that has existed in the Anglo-American legal system since the sixteenth century, have always meant that there can be an entity operating separate in personality from its owners.

Professor Robert W. Hillman points out that limited liability had existed in a variety of forms in Roman law, Islamic law and during medieval times. ${ }^{+}$Under Roman law, the head of the family was responsible for the torts of his slaves and sons. But he could offer the slave as a payment for the liability without incurring any extra liability. Similarly, the liability of the master's slaves or sons for debts incurred from contracts was limited by the amount of

He does so in the book, ibid. at 16, n. 28. In the movic, he spends a few minutes on this claim. The claim that the Supreme Court ignored the rights of $A$ fricun-Americans is a popular one, especially in light of its decision in Plessy v. Fergusson, 163 U.S. $537(1896)$, but not entirely accurute as Professors Bemstein and Somin argue in their book review of Michael J. Klarman's from Jim Crow to Civil Rights: The Supreme Court and the Struggle for Racial Equality (New York: Ox ford University Press, 2004)(David E. Bernstein \& llya Somin, "Judicial Power and Civil Rights Reconsidered" (2004) I 14 Yale L.J. 591 ). Lawrence H. Whilc, "Bankruptcy as an Economic Intervention" (1977) I Joumal of Libertarian Studies 281 at 286.

$4 \quad$ Robert W. Hillman, "Limited Liability in Historical Perspective" (1997) 54 Wash. \& Lee L. Rev. 6IS. 
assets that the master had authorized the slave or son to work with. The assets were known as the peculium, and interestingly the master could withdraw assets from the peculium at will, thereby insulating the master from debt liabilities incurred by the slave. It should be pointed out that it was in the master's interest to acquire a reputation for having a large peculium, as this would give those trading with his slave a better sense of security and level of trust. Therefore, the slave was the equivalent of the modern share. The slave conducted the business for the owner, with the owner suffering the maximum loss of the slave plus those assets in the peculium.

Islamic law had two similar mechanisms for limiting liability. The pledge of a slave as collateral to pay off debts incurred by the slave was one way of insulating the master from liability. The second was the development of the silent partner. Islamic law had a welldeveloped commercial law, most likely since its founder was a merchant himself. Much of Islamic law reflects the practices of the Arab merchants in the eighth century and earlier that did not explicitly contradict Quranic edicts such as the prohibition of the use of interest. Islamic legal texts usually contain an entire chapter on the law of partnerships. One form of partnership is the Qirad or Mudharaba whereby a silent partner would give his money to an investing manager who would share in the profits with the silent partner. The losses, however, would only be borne by the manager, thereby insulating the silent partner from any liability beyond the initial investment. This is the equivalent of the limited partnership whereby those who simply invest their money but take no part in the management of the partnership would be insulated from liability beyond the initial investment.

The Qirad was adopted as a limited partnership in eleventh-century Italy and emerged as the commenda, a limited partnership whereby passive investors financed sea trade. The compagnia emerged as the business vehicle for overland trade. The compagnia was similar to the commenda except in one respect: the passive investor did not enjoy limited liability. Over time, limited liability evolved into limited partnerships and ultimately the corporation. Andrew Carnegie, it should be noted, for example, ran his Carnegie Steel as a limited partnership. 5

John D. Rockefeller ran his Standard Oil as a trust whereby the shares of various companies were kept in trust for the owners with Rockefeller controlling the operations of the trust. ${ }^{6}$ For this reason, the act that governs competition law in the U.S. is known as the Sherman Antitrus $A c t .{ }^{7}$ In fact, simply because the limited liability corporation was suddenly available did not mean that it suddenly became an attractive form of business association. This is because creditors would not be willing to lend to limited liability companies without imposing a huge risk premium in the interest rate." Principles, 8th ed. (New York: Foundation Press. 2004) at 118.

libid.

15 U.S.C. $\$ 1$. Sec ibid.

An excellent source on the history of the company is John Micklethwait \& Adrian Wooldridge, The Company: A Short Jlistony of a Revolutionary ldea (New York: Modern Library, 2003). Sce also Michael Smart, "On limited liability and the development of capital markets: An historical analysis," Working Paper No. UT-ECIPA-SMART-96-02 (27 June 1996), online: University of Tomnto <www.economics.utoronto.ca/ecipa/archive/UT-ECIPA-MSMART-96-02.pds?. 
While unlimited liability may have been attractive to creditors, it imposed huge costs on the shareholders, which meant that only the truly wealthy or those able to lobby for a special charter from the state giving them limited liability would invest in any enterprise. It was precisely the advent of the railroad and the huge start-up costs associated with operating them that necessitated access to capital markets and a broader shareholder base. ${ }^{9}$ The rise of the modern company is quite intertwined with the railroad, as Bakan correctly points out. It was also the view of many social reformers, including Christian Socialists who wanted to enrich the poor and reduce class conflict, that allowing the masses access to investment opportunities via limited liability companies would be beneficial. ${ }^{10}$

Allowing limited liability meant that investors could purchase shares in companies without having to worry about losing their life's savings. Rather, the average person could partake in the wealth. Many companies, in fact, forced their employees to participate in the wealth by providing pension plans that were heavily invested in the company's shares - a practice that continues today. Furthermore, the evolution of corporate law from the law of partnerships and trusts meant that certain concepts that were operative in the law of partnerships would carry over to the law of corporations. The most important one is the concept that members of the board of directors are fiduciaries for the corporation." They are akin to trustees for an orphan or a guardian for a young child. Just as we would expect the trustee to take good care of the orphan's assets, shareholders should expect the board of directors to take good care of the corporation's assets. This analysis can therefore explain why Milton Friedman, the Nobel laureate in economics whom Bakan interviewed, argues that the only duty the corporation has is to maximize its profits. ${ }^{12}$ It is no accident, therefore, that the courts of equity took control over the law of corporations, since both trusts and partnerships were within equity's jurisdiction. ${ }^{13}$ This is why the law requires the directors of a corporation to maximize its profits - for anything less would be akin to an orphan's trustee wasting the orphan's assets.

Ultimately the issue, therefore, is not that the corporation is the vehicle of harm that Bakan claims it is. Rather, Bakan's complaint is against capitalism itself and the pursuit of profit by anyone. The corporation has allowed the pursuit of profit to become more efficient and be carried out on a mass scale, but abolishing the corporate form would do little in diminishing the pursuit of power, as limited liability vehicles have been carrying out business since ancient times. The attack on capitalism and the pursuit of profit is as old as time itself, and this review is not the place to deal with such an issue. The reader can read the numerous

Micklethwait \& Wooldridge, ibid. at 49-50.

lbid. at 50.

Imperial Mercantile Credit Association v. Coleman (1871), L.R. Ch. 558 (C.A.) [Imperial].

Milton F'riedman. "The Social Responsibility of Business is to Increase Its Profits" The New York Times: Maguzine (13 September 1970) 32.

Early English cases dealing with corporations were dealt with in the court of Chancery, e.g. Imperial, supro note 11. The state of Delaware, for example, where most of the U.S.'s large corporations are incorporated (Klein \& Coffec, supra notc 5 at 151, n. 47), continues to maintain courts of law and equity; it is the Court of Chancery that deals with corporate matters (online: Delaware State Courts <htip://courts.state.de.us/Cours/Court\%20of\%20Chancery>). 
texts that have been authored defending capitalism, ${ }^{14}$ but my point is to display that the real object of attack is the system that allows the pursuit of profit, rather than the vehicle by which we pursue it.

\section{ThE HARM THAT CORPORATIONS dO Through COST-BENEFIT ANALYSIS}

The corporation, Bakan tells us in chapters two to five, is an externalizing machine. It wreaks havoc on our environment, our wages and our health, and it does so with impunity. He gives several examples of corporate misdeeds, but I would like to focus on his attack on corporations using cost-benefit analysis when deciding what safety measures to take.

Throughout the book he condemns the practice of cost-benefit analysis conducted by corporations when deciding what safety measures to pursue. He cites the story of the woman who was driving her 1979 Chevrolet Malibu when another car slammed into her as she waited at a red light. The impact caused the fuel tank to explode and cause a fire that burned her children. She sued General Motors (GM) for the negligent design of the fuel tank. She alleged that it was too close to the rear bumper and that it had no proper metal brace to separate the tank from the rear. During the trial, a memo written in 1973 by a GM engineer was revealed to conclude that maintaining the current fuel tank was cheaper than designing a tank that did not explode in a crash. The analysis was done assuming that there would be 500 fatalities and that each fatality would cost $\$ 200,000$. He then estimated that since there were 41 million GM automobiles on the road, the cost per car to GM would be $\$ 2.40$. On the other hand, the cost of designing a non-exploding fuel tank was $\$ 8.59$ per car, and hence GM would save over $\$ 6$ per car by maintaining the status quo. It is this process of cost-benefit analysis that Bakan has exercised, and in his concluding chapter he calls for legislation that prohibits corporations from "acting in ways that are reasonably likely to cause harm, even if definitive proof that such harm will occur does not exist."15

There are several notable points that Bakan fails to mention regarding the GM case. ${ }^{16}$ The first is that the driver who rear-ended the Malibu was drunk with a blood alcohol level of 0.2 , more than twice the legal limit of 0.08 . Second, the Chevrolet Malibu had an excellent safety record, especially with respect to the fuel tank design. ${ }^{17}$ Furthermore, no evidence was presented to state that the memo was the definitive reason for the ultimate design that GM went with. But that is all secondary to the fundamental complaint that corporations engage in cost-benefit analysis. ${ }^{18}$

See e.g. Milton Friedman, Copitalism and Freedom (Chicago: University of Chicago Press, 2002); Milton Friedman \& Rose Friedman, Free to Choose: A Personal Statemem (New York: Harcourt Brace, 1990).

16 Margaret Cronin Fisk, "Nation's Largest Jury Verdict in '99 Has Ties to Fulton's GM Case" Fudton County Daily Report (28 February 2000): Mike MeKec, "\$4.8 Billion Award in GM case called 'Ludicrous' by Experts" The Recorder (12 July 1999) 2; "Litigation Lottery." Editorial, Imestor's Business Daily (26 August 1999) A22.

17 A search on the National Highway Traflic Saicty Administration (NHTSA) website reveals that there have been five defeets that necessitated recalls of the Malibu - none of them relating to the design of the fuel tank (online: NHTSA <www-odi.nhtsa.dot.gov/cars/problems/recalls/recallsearch.cfm>). 
The truth is that we all engage in cost-benefit analysis on a daily basis. There is always a risk of death when we take the bus or drive our own automobile to work every day, and yet we still make the trip. Not only is there a risk of death to us, but if we drive our own automobile, there is a risk that we may be the cause of someone else's death. And yet, no one would accuse us of putting dollars before safety. Many of us eat at restaurants knowing that there is a chance that the food may cause us an ailment or even death. When we cook for our guests, we are also creating a risk, however slight, that we may inadvertently poison our guests. No one, however, would claim that we should do all that is possible to eliminate all risk from our driving or cooking. That would be prohibitively costly.

Similarly, GM could construct an automobile that would never explode, never roll over and perhaps never suffer any dents when impacted by drunk drivers. The automobile would probably be stronger than a tank and cost the same. In fact, the law has always recognized that actors need not act to eliminate all risk of harm, just that which is feasible. The Learned Hand formula is the most famous articulation of this, and the common law has long recognized that no one can be called to lower risk beyond what is reasonable. ${ }^{19}$

But in addition to private individuals and corporations engaging in cost-benefit analysis, the state, the very body that Bakan hopes can tame the corporation, engages in such analysis on an order of magnitude far more harmful than what corporations engage in. The state designs highways and decides whether to install traffic lights at intersections, whether to remove the snow from city roads, whether to enforce traffic laws by spending money on the police, whether to save lives in high-crime neighbourhoods by paying for more police to conduct patrols and so on. These decisions are all fundamentally driven by a cost-benefit analysis, something the Supreme Court of Canada has sanctioned despite its well-known championing of individual rights. ${ }^{20}$

The Supreme Court of Canada held that British Columbia did not have to pay for an autistic boy's treatment despite the availability of programs that could help autism. The programs, however, could have cost up to $\$ 60,000$ per year. The Court held that the boy's parents did not establish that any discrimination had taken place and denied the relief sought by the parents, namely requiring the province to fund the treatment. When the decision of the Court was announced, the mother of an autistic girl was outraged, asking "Why do we have a Supreme Court of Canada, if they cannot uphold the Constitution and they cannot protect the most vulnerable members of sociely from the vagaries of government?"21 Her outrage is understandable, but any outrage should be no less than that aimed at GM. We have the choice as to which vehicle we purchase, and many manufacturers differentiate themselves in the market by exceeding the minimum safety requirements. The state, however, has

For more on the Learned Hand formula see Lewis Klar. Tort Law, 3d ed. (Toronto: Thomson Carswell, 2003) at 315. Oddly, the implicution of Bakan's criticism is that companies should not engage in any inquiry into whether there are any potential dangers from their product. This view seems to also be consistent with the observation that juries punish companies that investigate the costs and benefits of their products more than companies that remain ignorant (James Surowiecki, "Don'i Do the Math" The New Yorker (24 January 2005) 38.

: Auton (Guordian ad likem of) v. British Columbis (Altorney General), [2004] 3 S.C.R. 657, 2004 SCC 78.

"CBC News, "Top court: B.C. doesn't have to fund autism treatment" (22 November 2004), online: CBC News < www.cbc.ca/story/canada/national/2004/1 1/19/autism_supremecoun04 I 1 19.html>. 
mandated that we all participate in its universal health care system, denying the opportunity for any market provision of alternate health insurance schemes. Hence, when the state decides which programs to fund, leaving some vulnerable people to fend for themselves because of the prohibitive cost of their treatment, how is this any less outrageous than GM deciding what safety measures to undertake?

That, however, is not the worst of the state's cost-benefit analysis. The state violates our rights guaranteed by the Canadian Charter of Rights and Freedom $\mathrm{s}^{22}$ and does so with the blessing of the Canadian Constitution itself. Section 1 of the Charter states that "[t]he Canadian Charter of Rights and Freedoms guarantees the rights and freedoms set out in it subject only to such reasonable limits prescribed by law as can be demonstrably justified in a free and democratic society." Oddly enough, Canadians decided to start their Charter with this statement indicating that, while their rights are important, there are limitations that can apply, indicating that we as Canadians have collectively decided that we will allow the state to engage in cost-benefit analysis even when it comes to our sacred rights. ${ }^{23}$ It would seem odd that individuals, governments and the courts could engage in such analysis but not corporations (or for that matter partnerships or trusts). The truth is that cost-benefit analysis is something we all engage in, and rather than condemning it outright, it would be better to look into how to correct the calculus the firms engage in by, perhaps, addressing what the real costs are to society and how corporations can internalize these social costs.

Privatizing the environment so that corporations have a real stake in the environment might be one way to proceed. If corporations own the environment or at least have a financial stake in it, they will be more inclined to take care of it, since this will maximize its resale value. Corporations take good care of assets that they know they can resell as opposed to assets that have one-time use only. This viewpoint is discussed quite clearly in the Fraser Institute's Economics and the Environment: A Reconciliation. ${ }^{24}$ In fact, what empirical studies have been done show that privatization has led to improvements in the environment, contrary to the tales in The Corporation. Take, for example, the study by Sebastian Galiani, Paul Gertler and Ernesto Schargrodsky. ${ }^{25}$ They found that in Argentina, where water was privatized, child mortality fell 5 to 7 percent and that effect was largest in the poor areas (in fact, it was estimated to have fallen by up to 26 percent in the poorest areas) ${ }^{26}$ Studies like this should be used to investigate how social goals and the market can go hand in hand instead of seeking fundamental alterations to the system we live in. Elizabeth Brubaker also advocates privatization as a means for solving our environmental problems. ${ }^{27}$ She attributes the harm to the environment during the last century in Canada to legislatures that wiped out the property rights of communities by overturning court decisions that had established the

Part I of the Constitution Act. 1982, being Schedule B to the Canada Act 1982 (U.K.), 1982, c. 1 I [Charier].

For details on s. 1, see Peter W. Hogg, Constitutional Law of Canada, student ed. (Toronto: Thomson Carswell, 2003) at 777-825.

Walter Block. ed., Economics and the Emvironment: A Reconciliation (Vancouver: Fraser Institute. 1990).

Sebastian Galiani, Paul Gertier \& Emesto Schargrodsky, "Water for Life: The Impact of the Privatization of Water Services on Child Mortality" (2005) 113 Journal of Political Economy 83.

Ibid. at $115,105$.

Elizabeth Brubaker, Property Rights in the Defence of Nature (Toronto: Earthscan Publications Limited, 1995). 
common law rights of nuisance and trespass against polluting companies. When these statutes were passed, she points out, they were passed in the name of the public good. Rather than allowing the business owners and property owners to bargain among themselves, the state, the agency charged with protecting the public, acted contrary to the public's interest. It is this very state that Bakan would have us turn to for protection rather than the old common law, a system that developed largely uninfluenced by legislation and that protected us.

In fairness to Bakan, he does point out that corporations lobby governments to relax their regulatory standards. But this observation only weakens his attack on corporations. Abolishing the corporation and limited liability would only concentrate wealth in the hands of the few who could afford to face potential unlimited liabilities and would increase their lobbying efforts. The results would be a few wealthy families, rather than a diffuse distribution of wealth. The few would be able to lobby far more often and more effectively than the thousands of CEOs who exist today. In fact, the growing number of corporate crimes in the statute books belies the claim that corporations are growing more powerful. ${ }^{28}$

\title{
IV. Conclusion
}

The Corporation is a provocative book that should be read by all, for there are legitimate concerns that Bakan raises with the way our society is being managed. The question the reader must ask is whether abolishing the corporation and the pursuit of profit is the answer, or whether more state control is the answer. Those witnessing the current hearings into the financial scandals of the Liberal Party of Canada and the mismanagement by the state of the fisheries, forests and everything else it touches should remain skeptical. The challenge on the skeptics, then, is to articulate how the market is a superior solution to the state and to demonstrate that through the evidence. The skeptics need to also acknowledge where the market may not have best served society and address where such failures may have come from. Failing to do so will allow Bakan's seductive rhetoric to win the day.

\author{
Moin A. Yahya* \\ Assistant Professor \\ Faculty of Law \\ University of Alberta
}

2" Vikramaditya S. Khanna, "Politics and Corporate Crime Legislation" (2004) 27:I Regulation 30. I would like to thank Shannon O'Byme, Robern Chambers, James Stribopoulos and Ted DeCoste for helpful comments. All errors are mine. 